\title{
APPLE BIOLOGICAL AND PHYSIOLOGICAL DISORDERS IN THE ORCHARD AND IN POSTHARVEST ACCORDING TO PRODUCTION SYSTEM ${ }^{1}$
}

\author{
CARLOS ROBERTO MARTINS ${ }^{2}$, ALEXANDRE HOFFMANN ${ }^{3}$, CESAR VALMOR ROMBALDI ${ }^{4}$, \\ ROSELI DE MELLO FARIAS 5 , ADENIR VIEIRA TEODORO 6
}

ABSTRACT- The study aimed to evaluate the incidence of biological and physiological disorders in the field and postharvested apples cvs. Gala, Fuji and Catarina grown in four production systems: conventional, organic transition, integrated and organic. Apples were evaluated for damages related to biological and physiological disorders in the orchard and after harvest. The greatest damages were attributed to pests, especially Anastrepha fraterculus in the organic system and Grapholita molesta in the organic transition. Apples produced in organic orchards had higher damage levels caused by postharvest physiological disorders than those grown in other production systems. For apples becoming from organic orchards most of the damage was due to lenticels breakdown and degeneration ('Gala'), and bitter pit ('Fuji' and 'Catarina'). The incidence of postharvest rot was not influenced by apple production system.

Index terms: Apple tree, Malus domestica, organic production, integrated production.

\section{DISTÚRBIOS BIOLÓGICOS E FISIOLÓGICOS NO POMAR E NA PÓS-COLHEITA DE MAÇÃS EM FUNÇÃOO DO SISTEMA DE PRODUÇÃO}

RESUMO: O objetivo deste trabalho foi avaliar a ocorrência de distúrbios biológicos e fisiológicos, tanto em nível de campo como em pós-colheita, de maçãs 'Gala', 'Fuji' e 'Catarina', produzidas em pomares conduzidos em quatro sistemas de produção: convencional, transição convencional-orgânico, integrado e orgânico. As maçãs foram avaliadas quanto à presença de danos ocasionados por distúrbios biológicos e fisiológicos no pomar e em pós-colheita. Os maiores danos foram atribuídos às pragas, principalmente à Anastrepha fraterculus em sistema orgânico e à Grapholita molesta em sistema de transição convencionalorgânico. As maçãs produzidas em sistema orgânico tiveram maiores danos em pós-colheita ocasionados por distúrbios fisiológicos do que as dos demais sistemas de produção. Nas frutas produzidas em sistema orgânico, os danos, em sua maioria foram com degenerescência e depressão lenticelar para a cv. Gala, e bitter pit para as cvs. Fuji e Catarina. A incidência de podridões pós-colheita não foi influenciada pelo sistema de produção. Termos para indexação: Macieira, Malus domestica, produção orgânica, produção integrada.

\section{INTRODUCTION}

Apple production in Brazil is highlighted as one of the national fruit production chains that evolved the most in recent decades. Although the whole production process has achieved a good performance, the Brazilian apple production chain requires new technological solutions to enable at least the maintenance of current production, reduction of costs and improve fruit quality. Additionally, apple cultivation should allow the maximum preservation of natural resources helping to extend its exploration and survival of farmers. The region of São Joaquim, which lies in the southern state of Santa Catarina, Brazil, is characterized by its unique climate to produce high-quality apples. However, biological and physiological disorders pose the highest risks for apple production in this region.

Apple cultivation problems range from chronically mishandlings of cultivation techniques, excessive pesticide sprayings to wrong soil management strategies. Fruit trees grown in such conditions result in unbalanced plants which may be more sensitive to biological (pests and diseases) and

\footnotetext{
'(Trabalho 095-12). Recebido em: 27-02-2012. Aceito para publicação em: 29-11-2012. Parte da Tese de Doutorado apresentado pelo primeiro autor no Curso de Pós-graduação em Agronomia, Universidade Federal de Pelotas (UFPel), em Abril de 2004. Apoio: CAPES ${ }^{2}$ Engenheiro Agrônomo, Dr., Pesquisador da Embrapa Tabuleiros Costeiros. E-mail martins@cpatc.embrapa.br

${ }^{3}$ Engenheiro Agrônomo, Dr., Pesquisador da Embrapa Uva e Vinho. E-mail hoffmann@cnpuv.embrapa.br

${ }^{4}$ Engenheiro Agrônomo, Dr., Professor FAEM/UFPel. E-mail cesarvrf@ufpel.edu.br

${ }^{5}$ Engenheira Agrônoma, M.Sc. Professora da UERGS. E-mail roseli-farias@uergs.edu.br

${ }^{6}$ Engenheiro Agrônomo, Dr., Pesquisador da Embrapa Tabuleiros Costeiros. E-mail ad.teodoro@cpatc.embrapa.br
} 
physiological disorders, which in turn require farmers interference by adding external inputs and high-cost technologies in the agroecosystem (GONÇALVES; BOFF, 2002). The main physiological disorders of apple orchards are lack of calcium, bitter pit, lenticels breakdown, jonathan spot, internal breakdown, watercore and stem-end splitting (CURRY et al., 2008; AMARANTE, et al., 2009; AMARANTE et al., 2010). The biological disorders that cause major damage are the pests [South American fruit fly (Anastrepha fraterculus), the red mite (Panonychus ulmi)] and diseases [apple scab (Venturia inaequalis), bitter rot (Glomerella cingulata) and rotting (Phytophthora cactorum)]. In addition, growing management intensification has fostered other secondary disorders such as the apple leafroller (Bonagota cranaodes), the apple scale (Quadraspidiotus perniciosus), the oriental fruit moth (Grapholita molesta), the 'Gala' leaf spot (Colletotrichum spp.) and the white rot (Botryosphaeria dothidea). Farmers tackle biological disorders with intensive pesticide spraying which besides causing negative environmental impact affect biological control agents, resulting in a never-end fight against pests (MANZONI et al., 2006; GEIGER et al., 2011).

The intensification of conventional management practices have an impact mainly on the biodiversity of agroecosystems by negatively affecting ecological processes that are reflected in the production environment as well as nutritionally destabilizing the soil and the plant, increasing the incidence of biological and physiological disorders (REGANOLD, et al., 2001; CLOUGH et al., 2007; MIÑARRO et al., 2009 ). Such negative effects ultimately interfere in the production and postharvest quality of fruit besides burdening the production process and causing negative environmental impacts. Therefore, the full manifestation of the productive potential of apple plants and its relation with pests, diseases and physiological disorders are intrinsically related to interactions within a given production system.

This study aimed to evaluate the incidence of biological and physiological disorders at both the field and postharvest of apples grown in orchards conducted in conventional, transition from conventional to organic (hereafter 'organic transition'), integrated and organic production systems.

\section{MATERIAL AND METHODS}

The study was conducted in commercial orchards located in the municipality of São Joaquim, state of Santa Catarina, Brazil, during the 2001/2002 and 2002/2003 harvests. The climate is temperate mesothermal humid $\mathrm{Cfb}$ with mild summer according to the Köppen classification. The region has an annual average temperature of $13.5^{\circ} \mathrm{C}$, annual mean rainfall of $1.500 \mathrm{~mm}$ and annual average relative humidity of $81 \%$. The hottest months are January and February, the coldest are June and July, the wettest are August and September and the driest are December and January. 20 to 36 frosts occur annually and the number of annual hours of chilling below $7.2{ }^{\circ} \mathrm{C}$ is around 800 hours in this region.

Six-year old orchards of 'Fuji', 'Gala' and Catarina cultivars grown on Marubakaido rootstocks and conducted in conventional (CP), organic transition (OT), integrated (IP) and organic (OP) production systems were evaluated. Apple trees were conducted in central leader with $2.5 \mathrm{~m}$ within rows and $6.0 \mathrm{~m}$ between rows.

The study was carried out during two years to evaluate biological (pests and diseases) and physiological disorders by randomly sampling ten apple plants per cultivar in each production system. In each plant 100 fruit were randomly collected totaling 1.000 fruit per production system. Biological disorders attributed to diseases were evaluated by counting the number of fruit with rot and apple scab symptoms caused by Venturia inaequalis and other occasionally-occurring diseases during harvest. Symptoms of scabies were also evaluated on leaves by randomly selecting a branch located in a different quadrant of the equatorial zone of the plant during the previous evaluation. In this case each plant and each branch were considered as experimental units.

The disorders caused by pests were assessed by counting the number of fruit attacked by fruit flies, the oriental fruit moth Bonagota cranaodes and other pests. The incidence of physiological disorders was determined by the number of fruit with symptoms of russeting, cork spot and/or bitter pit. It was also evaluated the incidence of damage caused by phytotoxicity, stem-end splitting, discoloration, open lesions, healed tissues injuries and burning caused by the sun.

In order to evaluate postharvested fruit, they were collected in the ideal stage of maturation for storage, i.e., ground color yellowish green. Immediately after harvest fruit were selected, eliminating those with injuries, and standardized by the maturation stage. Fruit were maintained in a climate chamber at $0 \pm 1{ }^{\circ} \mathrm{C}$ and $93 \pm 5 \%$ relative humidity $(\mathrm{RH})$ at Embrapa Grape e Wine. Fruit were stored during three months for 'Gala' and five 
months for 'Fuji' and 'Catarina' were evaluated after seven days of shelf life at $20 \pm 3^{\circ} \mathrm{C}$ and $75 \pm 5 \% \mathrm{RH}$ at the postharvest laboratories of Embrapa Grape and Wine. When identifying the rot fruit they were sent for identification at the Laboratory of Plant Pathology at the same institution.

The study was arranged in a completely randomized design with ten replicates and each plant as an experimental unit. In postharvest and harvest for each cultivar, the experiment was conducted with five replicates with 20 fruit each. Variables with percentage values were transformed using $\mathrm{x}=\operatorname{arcsen} \sqrt{\mathrm{x} / 100}$ and $\operatorname{LOG}(\mathrm{x}+0.5)$ before being subjected to analysis of variance. All parameters were subjected to analysis of variance followed by Tukey tests $p<0.05$.

\section{RESULTS AND DISCUSSION}

The apple cultivars Gala and Fuji showed the highest incidence of leaves with symptoms of apple scab in conventional, followed by integrated and organic transition systems. No leaves with symptoms of apple scab were found in organic systems (Table 1). Independent of the production system, it was not detected symptoms of this disease in the cultivar Catarina (Table 1). Although there were differences in apple scab incidence on leaves among systems, this condition did not translated into fruit damage. The cultivars Fuji and Catarina had almost no damage caused by apple scab. However, the cultivar Gala had the highest incidence of this disease both in conventional and organic transition systems (Table 2 ). The apple scab is a serious disease of apples, especially in São Joaquim, where conditions are extremely favorable to its widespread dissemination. This disease consists of one of the main constraints for growing apples in any production system as it directly affects fruit quality besides causing a reduction in its size, premature defoliation, depletion and a poor development of fruit buds.

The incidence of rot on apples of the cultivar Gala was not related to the production system (Table 2). In the cultivars Fuji and Catarina grown in conventional and in organic transition systems, it was detected the highest percentage of rotting fruit in comparison to the remaining production systems. Rot on apples grown in organic transition system was mainly attributed to the stem-end-rot fungus (Cryptosporiopsis spp.), which is possibly linked to the attack of the oriental fruit moth (Table 2). The entrance of this infection is through lesioned fruit epidermis and lesions caused by pests and hail (SANHUEZA et al., 2010; SPOLTI et al., 2010).
The severity of diseases in organic systems might be reduced because the plant (host) would more be able to defend itself by being better nutritionally balanced and also by having a higher diversity of natural enemies which provided a more balanced environment. Together with alternative treatments with lower environmental impact, living with the disease can become more harmonious, without major damage to production. This is in line with other studies suggesting that organic apple production is not affected by the incidence of apple scab (SWEZEY et al., 1998; REGANOLD et al., 2001). Other studies, however, report that the apple scab, even in organic systems, causes considerable damage (PECK et al., 2006).

Regarding biological disorders caused by fruit flies, it was observed that the damage to apples of the cultivar Gala was higher on fruit coming from conventional and integrated systems, while the cultivar Fuji showed the greatest damage on fruit from organic and conventional orchards. For the cv. Catarina, however, the damage caused by fruit flies was not affected by the production system (Table 2).

The damage caused by the oriental fruit moth was high on apples grown in the organic transition orchard and intermediate on apples produced in the conventional orchard in comparison to the remaining production systems (Table 2).

Apple damage caused by Bonagota cranaodes and beetles was clearly influenced by the production system (Table 2). In relation to beetles, only the cv. Gala was affected regardless of production system. In this cultivar there were larger percentages of fruit attacked than those from conventional and organic orchards.

In another study, apples produced in organic systems showed no significant differences in damage caused by pests in comparison to other production systems even though organic systems had a higher diversity of natural enemies (SWEZEY et al., 1998; PECK et al., 2006). In another study comparing conventional and organic orchards, a higher number of beneficial insects in organic areas was found, probably due to the vegetation diversity within the orchard, however, it was not related to insect fruit damage which was higher in organic fields in the first years of evaluations. In the third year of assessment, however, the damage was almost negligible in both production systems (PECK, et al., 2006; MIÑARRO et al., 2009).

Regarding physiological disorders the cv. Gala grown in integrated and organic orchards had higher incidence of fruit russeting in comparison to conventional orchards (Table 3 ). However in the 
cultivars Fuji and Catarina similar fruit russeting levels were observed among systems, except for the cv. Fuji grown in the organic transition system that had a significantly lower incidence of this disease.

This disorder is characterized by rough epidermis with irregular dark brown patches, which aesthetically depreciates fruit. Russeting lowers fruit classification and consequently the value of the product. In addition to varietal susceptibility russeting is related to weather conditions (high temperatures and humidity at night, temperature variation, frost, hail, snow and wind) and chemical treatments. Copper-based products and zinc sulfate foliar fertilizers used mainly within 30 days after the fall of petals favor this disorder. This may be a problem in organic orchards, leading to preventive alternative sulfuric fungicide sprayings in addition to biofertilizers. This is in agreement with other studies that found higher incidence of fruit russeting in organic than in conventional orchards due to the intensive use of copper and sulfur.

Gala and Fuji had minor problems with skin fruit splitting as these apples cultivars were grown in organic transition orchards (Table 3). For the cv. Catarina there were no differences in skin splitting symptoms among systems. The cause of this disorder is often attributed to extreme moisture derived from heavy rainfalls followed by prolonged droughts, and excessive nitrogen coupled with low availability of calcium in fruit. These findings are in agreement with results of Martins et al. (2010) who found that although nitrogen content was similar between production systems all systems showed low levels of calcium in fruit pulp which favored cracking.

For other physiological disorders it was observed that sun burn stains and phytotoxicity, along with other damages such as open cicatrized injuries were not influenced by the production system in any cultivar (Table 3 ).

All cultivars were evaluated, but "Cork Spot" symptoms were only found in cv. Catarina. Apples had percentages of $7.7 \%$ in the integrated system, $6.0 \%$ in transition and $6.8 \%$ and in the organic system, meaning no significant differences among production systems. Both disorders are intrinsically related to the calcium nutrient (CURRY et al., 2008). Martins et al. (2010) also found low calcium content in fruit grown in the same production systems, especially in organic and in organic transition.

The major problems with physiological disorders during the postharvest of the 2001/2002 season were found in the cv. Gala, mainly produced in the organic system (Table 4). Degeneration was the most common physiological disorder in the apples grown in this production system. Apples of the cv. Gala produced in the integrated system also showed highest percentages of internal breakdown and stemend splitting. The incidence of other physiological disorders was not related to production systems.

In the 2002/2003 harvest, the incidence of physiological disorders in all production systems increased, and apples grown in the organic system had the highest percentages of such disorders (Table 3 ). The incidence of bitter pit, internal breakdown and stem-end splitting and internal ring cracking was not affected by production systems. Fruit produced in the organic orchard had significantly higher percentage of lenticels breakdown.

Lenticels Breakdown is a disorder closely related to bitter pit concerning the causes and symptoms. However, the development of this disorder occurs during the storage period and especially affects the skin. It is caused by calcium deficiency, excessive nitrogen fertilization and inadequate harvesting stage (CURRY et al., 2008). In both harvests the cvs. Fuji and Catarina suffered the most with physiological disorders when grown in the organic system and the lowest when produced in the integrated system (Table 4).

Apples produced in the organic system showed the highest level of fruit damage caused by physiological disorders than those grown in other production systems considering the three cultivars in the two harvests. The damage to fruit produced in the organic system was mostly related to lenticels and internal breakdown for the cv. Gala and bitter pit for the cvs. Fuji and Catarina. The incidence and severity with which calcium-related physiological disorders occur are closely linked to the production system as well as soil and climatic factors, varietal susceptibility, also varying over years (FERGUSON et al., 1999; CURRY et al., 2008; MARTINS et al., 2010). Also among the effects that predispose the development of these disorders are those affecting the translocation of calcium to the fruit and its contents in it, such as drought periods prior harvest, early harvest, orchard management (excessive pruning and thinning), unbalanced nutrition, plant age, position of fruit in the plant and leaf/ fruit ratio.

The percentage of rotting fruit was low and not influenced by production systems for the cvs. Gala and Fuji in both harvests (Table 5). Rotting found on fruit of the cvs. Fuji and Gala, regardless of the production system, were all identified as moldy core, which can be caused by pathogenic fungi of several genera. However, $98 \%$ of fungal isolates were Alternaria spp. and Fusarium spp. Moldy core is observed mainly 
on fruit stored under refrigeration for long periods.

The number of rotting apples of the $\mathrm{cv}$.

Catarina was not affected by the production system. Although no statistical differences were found, a trend of less rotting fruit was observed in organic orchards. Rots were identified as being of carpel origin, caused by the pathogenic fungi (Alternaria spp and Fusarim spp.). It was also identified the presence of alternaria rot (Alternaria alternata), blue mold (Penicillium expansum) and rot caused by Botrytis cinerea. The occurrence of decay associated with fungi such as A. alternata, Fusarim spp., P. expansum, B. cinerea and Rhizopus sp. are responsible for major losses in post-harvest apples.

TABLE 1- Percentage of leaves with apple scab (Venturia inaequalis) in the cvs. Gala, Fuji and Catarina in conventional (CP), organic transition (OT), integrated (IP) and organic (OP) orchards in São Joaquim-SC, 2012

\begin{tabular}{c|c|c|c}
\hline Production Systems & Gala & Fuji & Catarina \\
CP & $9,2 \mathrm{a}$ & $9,1 \mathrm{a}$ & - \\
IP & $7,5 \mathrm{ab}$ & $4,1 \mathrm{~b}$ & $0,0 \mathrm{~ns}$ \\
OT & $2,0 \mathrm{bc}$ & $3,2 \mathrm{~b}$ & 0,0 \\
OP & $0,0 \mathrm{c}$ & $0,0 \mathrm{c}$ & 0,0 \\
\hline
\end{tabular}

Same letters within columns denote no significant differences based on Tukey's test at 5\% probability. ns - not significant.

TABLE 2 - Biological disorders caused by rot, apple scab (Venturia inaequalis), fruit fly (Anastrepha fraterculus), oriental fruit moth (Grapholita molesta), apple leafroller (Bonagota cranaodes) and Coleoptera spp. on apples of the cvs. Gala, Fuji and Catarina in conventional (CP), integrated (IP), organic transition (OT) and organic (OP) orchards in São Joaquim-SC, 2012.

\begin{tabular}{|c|c|c|c|c|c|c|}
\hline $\begin{array}{c}\text { Production } \\
\text { Systems }\end{array}$ & Apple scab & Rot & Fruit fly & $\begin{array}{l}\text { Oriental fruit } \\
\text { moth }\end{array}$ & Apple leafroller & Coleoptera \\
\hline \multicolumn{7}{|c|}{ - } \\
\hline & \multicolumn{6}{|c|}{ GALA } \\
\hline $\mathrm{CP}$ & $2,8 \mathrm{ab}$ & $1,1 \mathrm{~ns}$ & $6,7 \mathrm{a}$ & $7,8 \mathrm{~b}$ & $8,6 \mathrm{~ns}$ & $2,5 \mathrm{ab}$ \\
\hline IP & $0,5 b$ & 0,7 & $7,0 \mathrm{a}$ & $0,2 \mathrm{c}$ & 4,5 & $1,2 \mathrm{~b}$ \\
\hline OT & $3,4 \mathrm{a}$ & 0,2 & $2,1 b$ & $15,7 \mathrm{a}$ & 6,1 & $0,7 \mathrm{~b}$ \\
\hline \multirow[t]{2}{*}{ OP } & $0,0 \mathrm{~b}$ & 1,3 & $3,1 \mathrm{~b}$ & $0,7 \mathrm{c}$ & 7,1 & $3,5 \mathrm{a}$ \\
\hline & \multicolumn{6}{|c|}{ FUJI } \\
\hline $\mathrm{CP}$ & $0,1 \mathrm{~ns}$ & $3,2 \mathrm{ab}$ & $2,6 \mathrm{ab}$ & $16,7 \mathrm{~b}$ & $2,6 \mathrm{~ns}$ & $0,2 \mathrm{~ns}$ \\
\hline IP & 0,0 & $2,1 b$ & $1,0 \mathrm{~b}$ & $0,1 \mathrm{c}$ & 1,6 & 0,4 \\
\hline OT & 0,1 & $5,2 \mathrm{a}$ & $1,0 \mathrm{~b}$ & $43,0 \mathrm{a}$ & 2,2 & 0,3 \\
\hline \multirow[t]{2}{*}{$\mathrm{OP}$} & 0,5 & $1,1 \mathrm{~b}$ & $5,1 \mathrm{a}$ & $0,9 \mathrm{c}$ & 3,4 & 1,5 \\
\hline & \multicolumn{6}{|c|}{ CATARINA } \\
\hline IP & $0,0 \mathrm{~ns}$ & $0,5 b$ & $2,2 \mathrm{~ns}$ & $0,0 \mathrm{~b}$ & $3,0 \mathrm{~ns}$ & $0,0 \mathrm{~ns}$ \\
\hline OT & 0,0 & $1,9 a$ & 1,4 & $14,6 \mathrm{a}$ & 2,0 & 0,4 \\
\hline $\mathrm{OP}$ & 0,1 & $0,5 \mathrm{~b}$ & 1,7 & $1,6 \mathrm{~b}$ & 2,2 & 1,0 \\
\hline
\end{tabular}

Same letters within columns denote no significant differences based on Tukey's test at $5 \%$ probability. ns - not significant. 
TABLE 3- Fruit damage caused by russeting, stem-end splitting, phytotoxicity, open lesion, cicatrized lesion and sun burning on apples of the cvs. Gala, Fuji and Catarina in conventional (CP), organic transition (OT), integrated (IP) and organic (OP) orchards in São Joaquim-SC, 2012.

\begin{tabular}{|c|c|c|c|c|c|c|}
\hline \multirow{2}{*}{$\begin{array}{l}\text { Production } \\
\text { Systems }\end{array}$} & Russeting & $\begin{array}{l}\text { Stem-end } \\
\text { splitting }\end{array}$ & Phytotoxicity & $\begin{array}{l}\text { Open } \\
\text { lesion }\end{array}$ & $\begin{array}{l}\text { Cicatrized } \\
\text { lesion }\end{array}$ & Sun Burning \\
\hline & \multicolumn{6}{|c|}{ GALA } \\
\hline $\mathrm{CP}$ & $2,3 c$ & $3,1 \mathrm{a}$ & $0,0 \mathrm{~ns}$ & $2,3 \mathrm{~ns}$ & $1,0 \mathrm{~ns}$ & $0,7 \mathrm{~ns}$ \\
\hline IP & $7,7 \mathrm{ab}$ & $2,5 \mathrm{a}$ & 0,0 & 3,1 & 0,7 & 0,8 \\
\hline OT & $5,5 \mathrm{bc}$ & $0,4 b$ & 0,2 & 1,5 & 0,4 & 0,0 \\
\hline \multirow[t]{2}{*}{$\mathrm{OP}$} & $11,5 \mathrm{a}$ & $3,0 \mathrm{a}$ & 0,0 & 1,8 & 3,1 & 1,9 \\
\hline & \multicolumn{6}{|c|}{ FUJI } \\
\hline $\mathrm{CP}$ & $4,2 \mathrm{a}$ & $1,3 \mathrm{ab}$ & $0,0 \mathrm{~ns}$ & $0,0 \mathrm{~ns}$ & $0,4 \mathrm{~ns}$ & $1,1 \mathrm{~ns}$ \\
\hline IP & $3,8 \mathrm{a}$ & $1,6 a b$ & 0,0 & 1,2 & 0,2 & 0,3 \\
\hline OT & $0,9 b$ & $0,3 b$ & 0,0 & 0,0 & 0,0 & 0,3 \\
\hline \multirow[t]{2}{*}{$\mathrm{OP}$} & $3,6 \mathrm{a}$ & $2,9 a$ & 0,0 & 1,4 & 0,5 & 0,8 \\
\hline & \multicolumn{6}{|c|}{ CATARINA } \\
\hline IP & $1,9 \mathrm{~ns}$ & $1,1 \mathrm{~ns}$ & $0,4 \mathrm{~ns}$ & $0,4 \mathrm{~ns}$ & $0,4 \mathrm{~ns}$ & $1,2 \mathrm{~ns}$ \\
\hline OT & 1,0 & 0,9 & 0,0 & 1,2 & 0,1 & 2,2 \\
\hline OP & 3,3 & 1,3 & 0,0 & 0,4 & 0,1 & 1,3 \\
\hline
\end{tabular}

Same letters within columns denote no significant differences based on Tukey's test at $5 \%$ probability. ns - not significant.

TABLE 4 - Physiological disorders on apples of the cvs. Gala, Fuji and Catarina grown in conventional (CP), integrated (IP), organic transition (OT) and organic (OP) orchards after storage in the 2001/2002 and 2002/2003 harvest seasons. São Joaquim- SC, 2012.

\begin{tabular}{|c|c|c|c|c|c|c|c|}
\hline \multirow{3}{*}{ Physiological disorders } & \multicolumn{3}{|c|}{$2001 / 2002$} & \multicolumn{4}{|c|}{$2002 / 2003$} \\
\hline & $\mathrm{CP}$ & IP & OP & $\mathrm{CP}$ & IP & OT & OP \\
\hline & \multicolumn{7}{|c|}{ Gala } \\
\hline Bitter pit & $0 \mathrm{~ns}$ & 2,67 & 2,67 & $8,00 \mathrm{~ns}$ & 5,33 & 2,67 & 5,33 \\
\hline Lenticels breakdown & Ons & 0 & 0 & $1,33 b$ & $0,00 \mathrm{~b}$ & $1,33 b$ & $10,67 \mathrm{a}$ \\
\hline Internal breakdown & $1,33 b$ & $4,00 \mathrm{ab}$ & $10,67 \mathrm{a}$ & Ons & 0 & 0 & 1,33 \\
\hline Stem-end plitting & $1,33 b$ & $4,0 \mathrm{a}$ & ob & $2,67 \mathrm{~ns}$ & 6,67 & 4,00 & 4,00 \\
\hline Internal ring cracking & Ons & 0 & 0 & $9,33 \mathrm{~ns}$ & 4,00 & 5,00 & 1,33 \\
\hline \multirow[t]{2}{*}{ Total $(\%)$} & $2,66 \mathrm{~b}$ & $10,67 \mathrm{ab}$ & $13,33 \mathrm{a}$ & $21,33 \mathrm{~ns}$ & 16,00 & 13,00 & 22,67 \\
\hline & \multicolumn{7}{|c|}{ Fuji } \\
\hline Bitter pit & $2,66 \mathrm{~b}$ & $0 \mathrm{~b}$ & $12,00 \mathrm{a}$ & $4,00 \mathrm{~ns}$ & 0 & 1,33 & 3,33 \\
\hline Lenticels breakdown & Ons & 0 & 1,33 & Ons & 0 & 0 & 1,33 \\
\hline Internal breakdown & $0 \mathrm{~b}$ & $0 b$ & $3,00 \mathrm{a}$ & $1,33 \mathrm{~ns}$ & 0 & 0 & 0 \\
\hline Cork breakdown & Ons & 1,33 & 0 & Ons & 1,33 & 4,00 & 4,00 \\
\hline Stem-end plitting & $4,00 \mathrm{~ns}$ & 6,67 & 2,67 & $1,33 \mathrm{~ns}$ & 3,67 & 1,33 & 3,00 \\
\hline Internal ring cracking & $4,00 \mathrm{~ns}$ & 2,00 & 2,67 & Ons & 1,33 & 1,33 & 1,33 \\
\hline \multirow[t]{2}{*}{ Total $(\%)$} & $10,66 \mathrm{~b}$ & $10,00 \mathrm{~b}$ & $21,67 \mathrm{a}$ & $6,66 \mathrm{~ns}$ & 5,33 & 7,99 & 12,99 \\
\hline & \multicolumn{7}{|c|}{ Catarina } \\
\hline Bitter pit & * & $12,00 \mathrm{~b}$ & $34,67 a$ & $*$ & $8,00 \mathrm{~b}$ & $32,00 \mathrm{a}$ & $32,00 \mathrm{a}$ \\
\hline Lenticels breakdown & & $12,00 \mathrm{a}$ & $1,33 b$ & & Ons & 0 & 2,67 \\
\hline Cork breakdown & & $2,67 \mathrm{~ns}$ & 1,33 & & Ons & 0 & 0 \\
\hline Internal breakdown & & $1,33 \mathrm{~ns}$ & 0 & & Ons & 0 & 1,33 \\
\hline Stem-end plitting & & Ons & $4,00 \mathrm{~s}$ & & $1,33 \mathrm{~ns}$ & 0 & 1,33 \\
\hline Internal ring cracking & & Ons & 1,33 & & Ons & 1,33 & 0 \\
\hline Scald superficial & & Ons & 1,33 & & Ons & 2,67 & 0 \\
\hline Total & & $28,00 \mathrm{~ns}$ & 43,99 & & $9,33 b$ & $36,00 \mathrm{a}$ & $37,33 \mathrm{a}$ \\
\hline
\end{tabular}

Same letters within line denote no significant differences based on Tukey's test at 5\% probability. ns - Not significant. * Not evaluated 
TABLE 5- Apple rotting on fruit of the cvs. Gala, Fuji and Catarina grown in conventional (CP), integrated (IP), organic transition (OT) and organic (OP) orchards after storage in the 2001/2002 and 2002/2003 harvest seasons. São Joaquim- SC,2012.

\begin{tabular}{|c|c|c|c|c|c|c|c|}
\hline \multirow{2}{*}{ Cultivars } & \multicolumn{3}{|c|}{$2001 / 2002$} & \multicolumn{4}{|c|}{$2002 / 2003$} \\
\hline & $\mathrm{CP}$ & IP & $\mathrm{OP}$ & $\overline{\mathrm{CP}}$ & IP & OT & $\overline{\mathrm{OP}}$ \\
\hline Gala & $0 \mathrm{~ns}$ & 4,0 & 0 & $1,3 \mathrm{~ns}$ & 0 & 1,3 & 0 \\
\hline Fuji & $12,0 \mathrm{~ns}$ & 12,0 & 0 & $2,6 \mathrm{~ns}$ & 4,0 & 4,0 & 0 \\
\hline Catarina & -* & $5,3 \mathrm{~ns}$ & 4,0 & $-*$ & $5,3 \mathrm{~ns}$ & 9,3 & 4,0 \\
\hline
\end{tabular}

Same letters within columns denote no significant differences based on Tukey's test at 5\% probability. ns - not significant. *Not evaluated.

\section{CONCLUSION}

Overall, biological disorders caused by pests are greater than those related to diseases. The attack of pests such as fruit flies proves to be the greatest obstacle to organic production system while the greatest damage to apples in organic transition is the oriental fruit moth. The incidence of apple scab on fruit is not influenced by the systems studied. Apples produced in the organic system show higher damage caused by postharvest physiological disorders than those of other production systems, indicating that nutritional input should be monitored. Also, most of the damage to apples produced in the organic system is due to internal and lenticels breakdown for the cv. Gala, and bitter pit for the cvs. Fuji and Catarina. The incidence of postharvest rots is not influenced by the production system.

\section{ACKNOWLEDGEMENTS}

Capes and CNPq by the scholarship and financial research support.

\section{REFERENCES}

AMARANTE, C. V. T.; ERNANI, P.R.; STEFFENS C. A. Predição de "bitter pit" em maçãs 'gala' por meio da infiltração dos frutos com magnésio. Revista Brasileira de Fruticultura, Jaboticabal, v. 31, n. 4, p. 962-968, 2009.

AMARANTE, C. V. T.; STEFFENS, C. A.; BLUM, L. E. B. Coloração do fruto, distúrbios fisiológicos e doenças em maçãs 'Gala' e 'Fuji' pulverizadas com aminoetoxivinilglicina. Revista Brasileira de Fruticultura, Jaboticabal, v.32, n.1, p. 9-18, 2010.
CLOUGH, Y.; KRUESS, A.; TSCHARNTKE, T. Organic versus conventional arable farming systems: Functional grouping helps understand staphylinid response. Agriculture, Ecosystems \& Environment, Amsterdam, v.118, p.285-290, 2007.

CURRY, E. A.; TORRES,C.; NEUBAUER, L. Preharvest Lipophilic Coatings Reduce Lenticel Breakdown Disorder in 'Gala' Apples. HortTechnology, Alexandria, v.18, n.4, p.690-696, 2008.

FERGUNSON, I.; VOLZ, R.; WOOLF, A. Preharvest factors affecting physiology disorders of fruit. Postharvest Biology and Technology, Amsterdam, v.15, p.255-262, 1999.

GEIGER, F.; BENGTSSON, J.; BERENDSE, F.; WEISSER, W.W.; EMMERSON, M.; MORALES, M.B.; CERYNGIER, P.; LIIRA, J.; TSCHARNTKE, T.; WINQVIST, C.; EGGERS, S.; BOMMARCO, R.; PAERT, T.; BRETAGNOLLE, V.; PLANTEGENEST, M.; CLEMENT, L.W.; DENNIS, C.; PALMER, C.; OÑATE， J.J.; GUERRERO, I.; HAWRO, V.; AAVIK, T.; THIES, C.; FLOHRE, A.; HAENKE, S.; FISCHER, C.; GOEDHART, P.W.; INCHAUSTI, P.W. Persistent negative effects of pesticides on biodiversity and biological control potential on European farmland. Basic and Applied Ecology, Jena, v.11, p. 97-105, 2011.

GONÇALVES, P. A. S.; BOFF, P. Manejo agroecologico de pragas: Conceitos e Definições. Agropecuária Catarinense, Florianópolis, v.15, n.3, p. 51-54, 2002. 
MANZONI, C.G.; GRÜTZMACHER, A.D.; GIOLO, F.P.; LIMA, C.A.B. de.; NÖRNBERG, S.D.; HARTER, W.DA.R.; MÜLLER, C. Seletividade de agrotóxicos recomendados na produção integrada de maçã a Trichogramma pretiosum Riley, 1879 (Hym.: Trichogrammatidae) em condições de laboratório. Revista Brasileira de Fruticultura, Jaboticabal, v.28, n.2, p.254-257, 2006.

MARTINS, C. R.; FARIA, J. L. C.; ROMBALDI, C. V.; FARIAS, R. M. F. Qualidade Sensorial de Maçãs produzidas em diferentes sistemas de produção. Scientia Agraria, Curitiba, v. 11, p. 91-99, 2010.

MIÑARRO, M.; ESPADALER, X.; MELERO, V.X; SUÁREZ-ÁLVAREZ, V. Organic versus conventional management in an apple orchard: effects of fertilization and tree-row management on grounddwelling predaceous arthropods. Agricultural and Forest Entomology, Oxford, n.11, p.133-142, 2009.

PECK, G.M., P.K. ANDREWS, J.P. REGANOLD, AND J.K. FELLMAN. Apple orchard productivity and fruit quality under organic, conventional, and integrated management. HortScience, Alexandria, v.41, p. 99-107, 2006.
REGANOLD, J.P, GLOVER, J.D; ANDREWS, P.K, HINMAN,H.R. Sustainabilty of three apple production systems. Nature, London, n.410, p.926930, 2001.

SANHUEZA, R.M.; SPOLTI, P.; DEL PONTE, E.M. Control of initial inoculum for reducing losses by bull's eye rot on apples. Revista Brasileira de Fruticultura, Jaboticabal. v 32, n.4, p.1044-1054, 2010.

SPOLTI, P.; SANHUEZA, R.M.;DEL PONTE, E.M. Meio semisseletivo para recuperação e quantificação de Cryptosporiopsis perennans em maçãs. Ciência Rural, Santa Maria, v. 40, n.3, p.661-665, 2010.

SWEZEY, L.S.; WERNER, M.R; BUCHANAN, M.; ALISON, J. Comparison of conventional and organic apple production systems during three years of conversion to organic management in coastal California. American Journal of Alternative Agriculture, v.13, n.4, p.162-180, 1998. 